\title{
Development of a Multiplex Event-specific PCR Assay for Detection of Genetically Modified Rice
}

\author{
J. LU ${ }^{1,2 *}$, G.Z. JI ${ }^{1,2 *}$, G. $\mathrm{LI}^{2,3}$, Y.F. $\mathrm{WU}^{2}$, J. YANG ${ }^{2}$, S.L. $\mathrm{LIN}^{2}$, D.L. YANG ${ }^{2,3}$, \\ J.N. ZHAO ${ }^{1,2,3}$ and W.M. XIU ${ }^{1,2,3 * *}$ \\ ${ }^{1}$ College of Plant Protection, Shenyang Agricultural University, Shenyang 110866, China \\ ${ }^{2}$ Agro-Environmental Protection Institute, Ministry of Agriculture, Tianjin 300191, China \\ ${ }^{3}$ Tianjin Engineering Research Center of Agricultural Ecological \& Environmental Remediation, \\ Tianjin 300191, China
}

(Received 30 January 2015; Accepted 15 May 2015)

\begin{abstract}
Global rice supplies have been found contaminated with unapproved varieties of genetically modified (GM) rice in recent years, which has led to product recalls in several of countries. Faster and more effective detection of GM contamination can prevent adulterated food, feed and seed from being consumed and grown, minimize the potential environmental, health or economic damage. In this study, a simple, reliable and cost-effective multiplex polymerase chain reaction (PCR) assay for identifying genetic modifications of TT51-1, Kemingdao1 (KMD1) and Kefeng6 (KF6) rice was developed by using the event-specific fragment. The limit of detection (LOD) for each event in the multiplex PCR is approximately $0.1 \%$. Developed multiplex PCR assays can provide a rapid and simultaneous detection of GM rice.
\end{abstract}

Keywords: multiplex polymerase chain reaction, genetically modified rice, detection, event-specific

\section{Introduction}

The global area of GM plants has a 100-fold increase from 1.7 million hectares in 1996 to over 175 million hectares in 2013 (James 2013). The genetic compositions of genetically modified products (GMPs) have been altered by a gene modification technique to gain new characteristics, like herbicide tolerance, insect resistance or modified nutritional composition (Arun et al. 2013). Rice (Oryza sativa) is one of the most important food crops in the world, especially in many Asian countries. Worldwide, more than 3.5 billion people have rice for more than $20 \%$ of their daily calorie intake (Seck et al. 2012), therefore, the development of genetically modified rice is of high priority. The herbicide resistance and insect-resistant GM events are the most advanced GM rice. GM rice TT51-1, KMD1 and KF6 are three of the most well-known events (Chen et al. 2012). TT51-1 is an insect-resistant transgenic rice event harboring a hybrid $c r y 1 A b / A c$ gene driven by rice actin 1 gene promoter and the nopaline synthase (NOS) terminator, which was granted

\footnotetext{
* These authors contribute equally to this paper.

**CCorresponding author; E-mail: xiuweiming@caas.cn; Phone: +86-22-236 11815
} 
the safety certificate by China in 2009 (Tu et al. 2003; Lu 2010). The transgenic Chinese $\mathrm{Bt}$ rice KMD1, derived from the commercial japonica rice variety Xiushui11 (XS11) by Agrobacterium transformation with a synthetic crylAb gene (Babekova et al. 2008; Liu et al. 2012), is resistant to eight lepidopteran pest species like the yellow stem borer, the striped stem borer and the rice leaf folder, which has the potential to be approved in China (Babekova et al. 2009). KF6 contains two insect-resistant genes, crylAc gene under the control of the maize ubiqutin promoter and $C p T I$ (cowpea trypsin inhibitor) gene (Rong et al. 2005).

Unlike other major crops, the commercial cultivation of GM rice is authorized only in a very limited number of countries (James 2010). Three herbicide-resistant GM rice varieties (LLRICE06, LLRICE62 and LLRice601) were approved for commercial cultivation in the USA (CERA 2010). Biosafety certificates were issued for the Bt rice lines Huahui No. 1 and Bt Shanyou 63 ("Bt63") by China's Ministry of Agriculture in 2009 (Chen et al. 2011). Furthermore, a number of other GM rice varieties were also under development in China (Kluga et al. 2013), but commercial production of GM rice is still not permitted in China. In the following years also in Iran GM rice could be commercialized on a larger scale (Ghareyazie 2012). Until today, no GM varieties of rice have been commercialized at a large scale, but global rice supplies have been found contaminated with unapproved varieties of GM rice in recent years. Illegal cultivation and trade of GM rice in China was reported in 2005 ( $\mathrm{Zi}$ 2005). Rice contaminated with unauthorized LLRICE601 has been found across the world in 2006 (GM Contamination Register 2007). Since 2006, trace amounts of several unapproved Chinese GM rice (e.g. TT51-1 (synonym BT63), KMD1 and KF6) in food products on the EU market have also been notified to the rapid alert system for food and feed (RASFF) (see the notifications at https://webgate.ec.europa.eu/rasff-window/portal/). Following the repeated RASFF notifications of GM rice from China, the EU implemented a new regulation concerning rice from China, replacing decision 2008/289/EC (Bt63 rice). Decision No. 2011/884/EU which became effective since January 11th 2012, requires systematic screening for genetic modifications of rice products from China that are intended for the European market (The Health and Consumers Directorate-General of the European Commission 2012). Lately, genetic modifications in Basmati rice originated from Pakistan or India have been detected for the first time in products placed on the EU market in autumn 2011 (Reiting et al. 2013).

The targets for PCR-based GMO tests can be grouped into at least four categories contained screen-specific, gene-specific, construct-specific and event-specific (Zhang and Guo 2011). The event-specific PCR targets the unique and specific junction sequences between the transgenic insert and the plant genome DNA (Yang et al. 2007). Some eventspecific PCRs have been accredited or validated for the nucleic acid detection by official bodies/reference laboratories, and are currently the most widely used DNA detection methods for determining the presence of GMOs content in processed food and feed samples for the high specificity (Dong et al. 2008).

In order to monitor the presence of TT51-1, KMD1 and KF6, which are found contaminating food products not only in China but as well as in EU and have been reported many times, simple and effective detection methods are needed urgently. Real-time PCR 
assays and loop-mediated isothermal amplification (LAMP) assays for KMD1, TT51-1 and KF6 have been reported (Babekova et al. 2009; Wu et al. 2010; Cao et al. 2011; Chen et al. 2012). However, multiplexing can provide a cost effective diagnostic assay for GM detection with higher throughput and less consumption of samples and reagents as compared to simplex assays (Bahrdt et al. 2010; Kim et al. 2013; Kim et al. 2014). Our goal is to develop a simple, reliable and cost-effective multiplex PCR assay for simultaneous detection of genetic modifications of TT51-1, KMD1 and KF6 rice to meet the above monitoring requirement.

\section{Materials and Methods}

\section{Plant materials}

GM rice (TT51-1, KMD1, KF6) and Non-GM rice (New Liangyou6, Liangyou6326, Y Liangyou1, Zaoxian788) were collected by our laboratory.

\section{Methods}

\section{DNA extraction and purification}

DNA extraction was carried out following the cetyl-trimethylammoniumbromide (CTAB) protocol (Dellaporta et al. 1983). The purity and concentration of extracted DNA were measured and analyzed by an ultraviolet (UV) spectrophotometer (BioPhotometer plus, Eppendorf). The quality of the extracted DNAs was evaluated from the ratio of UV absorptions at 260/280 and 260/230 nm wavelengths.

\section{PCR primers}

A total of four sets of primer pairs were designed for multiplex PCR to detect and distinguish three varieties of GM rice. The rice sucrose phosphate synthase (SPS) gene (Accession no. U33175) as an endogenous reference gene has been applied in the national standards of China and undergone an international collaborative study (Ding et al. 2004; Jiang et al. 2009). The primers TT51-F/R, KMD1-F/R and KF6-F/R were designed based on the revealed integration junction region sequences plated between the rice genome and integrated foreign genes of TT51-1 (Accession no. EU880444.1), KMD1 (Accession no. EU980363.1) (Babekova et al. 2009), KF6 (Accession no. HM124449) (Wang et al. 2011). The sequences of the oligonucleotide primers used in this study were listed in Table 1. All oligonucleotide primers used were synthesized by Sangon Biotechnology Co. Ltd. (Shanghai, China).

\section{PCR conditions}

All PCR reactions were carried out in thermal cycler (Eppendorf Mastercycler ${ }^{\circledR}$ ep gradient S). The multiplex PCR reaction mixture in $25 \mu \mathrm{L}$ volumes contained $100 \mathrm{ng}$ of 
Table 1. Primers used in this study

\begin{tabular}{|c|c|c|c|}
\hline Primer & Sequence $\left(5^{\prime}-3^{\prime}\right)$ & Targets & Amplicon length (bp) \\
\hline TT51-F & CGACTCTAGAGGATCCCG & T-DNA & \multirow{2}{*}{200} \\
\hline TT51-R & CTCTGAGGATCCAAACAAGGC & Genome & \\
\hline KMD1-F & AAGCGTCAATTTGTTTACACC & T-DNA & \multirow{2}{*}{175} \\
\hline KMD1-R & CCTGTCAGTCTCGTCAGCAA & Genome & \\
\hline KF6-F & CCTATGATGTTATCCCATGC & Genome & \multirow{2}{*}{151} \\
\hline KF6-R & AAAACGTCCGCAATGTGT & T-DNA & \\
\hline SPS-F & ATCTGTTTACTCGTCAAGTGTCATCTC & SPS & \multirow{2}{*}{287} \\
\hline SPS-R & GCCATGGATTACATATGGCAAGA & SPS & \\
\hline
\end{tabular}

genomic DNA, $2.5 \mu \mathrm{L}$ of $10 \times$ buffer (Takara, Dalian, China), $200 \mu \mathrm{M}$ of each dNTP (Takara), $1.5 \mathrm{mM}$ of $\mathrm{MgCl}_{2}$, and 0.65 units of Hot Start Taq polymerase (Takara). The concentration of primers for each target gene from $0.2 \mu \mathrm{M}$ to $12 \mu \mathrm{M}$ was adjusted independently until the PCR products showed similar intensities after agarose gel electrophoresis. Final concentrations of primers (SPS-F/R $0.25 \mu \mathrm{M}, \mathrm{TT} 51-\mathrm{F} / \mathrm{R} 10 \mu \mathrm{M}, \mathrm{KMD} 1-\mathrm{F} / \mathrm{R}$ $0.54 \mu \mathrm{M}, \mathrm{KF} 6-\mathrm{F} / \mathrm{R} 5.6 \mu \mathrm{M})$ were included in each reaction. The reaction conditions of multiplex PCR were the following: initiation step of $3 \mathrm{~min}$ at $94{ }^{\circ} \mathrm{C}$ followed by 50 cycles of $30 \mathrm{~s}$ at $94{ }^{\circ} \mathrm{C}, 30 \mathrm{~s}$ at $61{ }^{\circ} \mathrm{C}$ and $30 \mathrm{~s} 72{ }^{\circ} \mathrm{C}$, final extension at $72{ }^{\circ} \mathrm{C}$ for $7 \mathrm{~min}$. The concentration of primer pairs was $0.4 \mu \mathrm{M}$ in the conventional simplex PCR. The thermal cycling condition was set as $3 \mathrm{~min}$ at $94{ }^{\circ} \mathrm{C}, 40$ cycles of $30 \mathrm{~s}$ at $94{ }^{\circ} \mathrm{C}, 30 \mathrm{~s}$ at $58{ }^{\circ} \mathrm{C}$ and $30 \mathrm{~s}$ at $72{ }^{\circ} \mathrm{C}$, final extension at $72^{\circ} \mathrm{C}$ for $7 \mathrm{~min}$. All PCR products were separated and identified based on the length of the amplified DNA fragments after electrophoresis in a $3 \%$ agarose gel in $1 \times$ TAE buffer [40 mM Tris-acetate $(\mathrm{pH} 8.0), 1 \mathrm{mM}$ EDTA] with ethidium bromide (EB) (Sigma, US), evaluated by the gel imaging system (Gel Dox XR system, Bio-Rad). The 50 bp DNA ladder (Takara) was used as a size standard for amplified DNA fragments. Sequencing of PCR products was performed by Sangon Biotechnology Co. Ltd. (Shanghai, China).

\section{Results}

Specificity of the multiplex PCR

We designed event-specific primers targeting three GM rice events, TT51-1, KMD1 and KF6. In order to evaluate and verify the specificity of primer pairs designed for multiplex $\mathrm{PCR}$, the performance of each individual pair of primers in the conventional simplex PCR was carried out using the genomic DNA templates from GM and non-GM materials as follows: GM rice TT51-1, GM rice KMD1, GM rice KF6 and non-GM rice. PCR products were observed under ultraviolet light after electrophoresis. As shown in Fig. 1, endogenous gene SPS was normally amplified. The expected amplifications were specifically amplified from each target GM rice (TT51-1, KF6 and KMD1), but not those from 
the non-GM rice, indicating the high specificity of the primer pairs. The three target amplifications from GM rice were identified by DNA sequencing analysis and found to have the correct target sequences (Fig. 2).

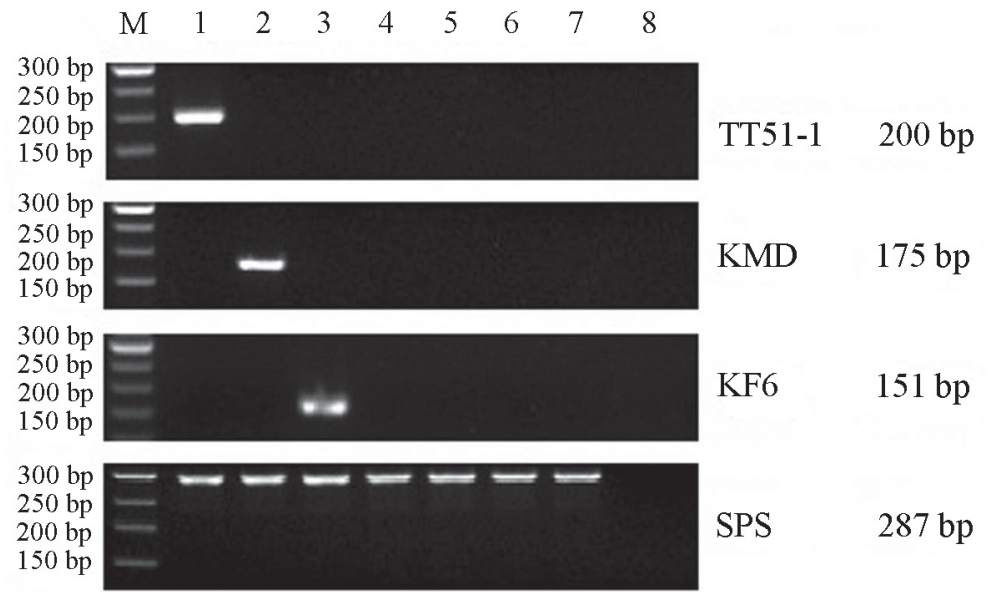

Figure 1. A conventional simplex PCR assay analysis of the specificity of primer pairs designed for multiplex PCR. Lane M, 50 bp DNA ladder; Lane 1, TT51-1; Lane 2, KMD1; Lane 3, KF 6; Lanes 4-7, Non-GM rice (New Liangyou 6, Liangyou 6326, Y Liangyou 1, Zaoxian 788); Lane 8, environmental control, no template

\section{A 1 CGACTCTAGAGGATCCCGGACGAGTGCTGGGGCAGATAAGCAGTAGTGGTGGGGCTACGA 61 ACATATTCCTTTTCCTTCTGGACGCTACCACTCATATGTTCCAAAATTACAAATTTGTCC 121 TTTGTATTTGTTGCAATTTTCATGTAAGAAATCCAACGAGGCTCTGTTTTTTTTTATTGG 181 CCTTGTTTGGATCCTCAGAG}

\section{B 1 CCTATGATGTTATCCCATGCTAATGTATCCAGAGCGATGGCTTGCTTTGAGCACTCTAAT 61 TTCTTCAAAGTAACGGCGCCGGAGGCACGACCCGGCCAGTTAAGGCCAGGAGCGCATCTG 121 ATCCAACTTAATAACACATTGCGGACGTTTT}

\section{1 AAGCGTCAATTTGTTTACACCACAATATATCCCGAGATGGGCAGGCATATCGGCGTACGC 61 ACGCAGCCCGGTGAGACCCGCCGCAGTTGGAGCGCGCATCGCCATCGCCGCGAGCCCGCG 121 AAGTCCACGGCGCCCTCGTCGGCGGAACACCCCAGTTGCTGACGAGACTGACAGG}

Figure 2. Flanking sequences of the transferred DNA flanking region and the inserted region of the GMO genome from three GM rice PCR products. A, 3 ' flanking sequences of TT51-1, the PCR product is 200-bp long. B, 5 ' flanking sequences of KMD, the PCR product is 175-bp long. C, 3 ' flanking sequences of KF6, the PCR product is 151-bp long. The primers are underlined. The rice genome sequence is shaded 


\section{Sensitivity of the multiplex PCR}

To develop a reliable, cost-effective and rapid multiplex PCR assay, factors which could influence the detection need to be considered. These factors include the sequence, specificity, concentration and annealing temperature of the primers, etc. Among these factors, the development of suitable primers is much more critical in multiplex PCR than in conventional PCR. In this study, primer concentrations were optimized in order to avoid common constraints like non-specific product amplification or cross-amplification reactions and generate specific PCR products with equal efficiency. The concentration of primers for each target gene from $0.2 \mu \mathrm{M}$ to $12 \mu \mathrm{M}$ was adjusted independently until the PCR products showed similar intensities after agarose gel electrophoresis. Figure 3 showed the results of multiplex PCR using the optimized conditions. Final concentration of primers (SPS-F/R 0.25 $\mu \mathrm{M}$, TT51-F/R $10 \mu \mathrm{M}, \mathrm{KMD} 1-\mathrm{F} / \mathrm{R} 0.54 \mu \mathrm{M}, \mathrm{KF} 6-\mathrm{F} / \mathrm{R} 5.6 \mu \mathrm{M}$ ) were included in the same PCR run. In optimized multiplex PCR the expected target sequences for each GM rice event and the SPS gene were specifically amplified and showed similar intensities. These PCR results indicate that this method is sufficient to distinguish three GM rice events.

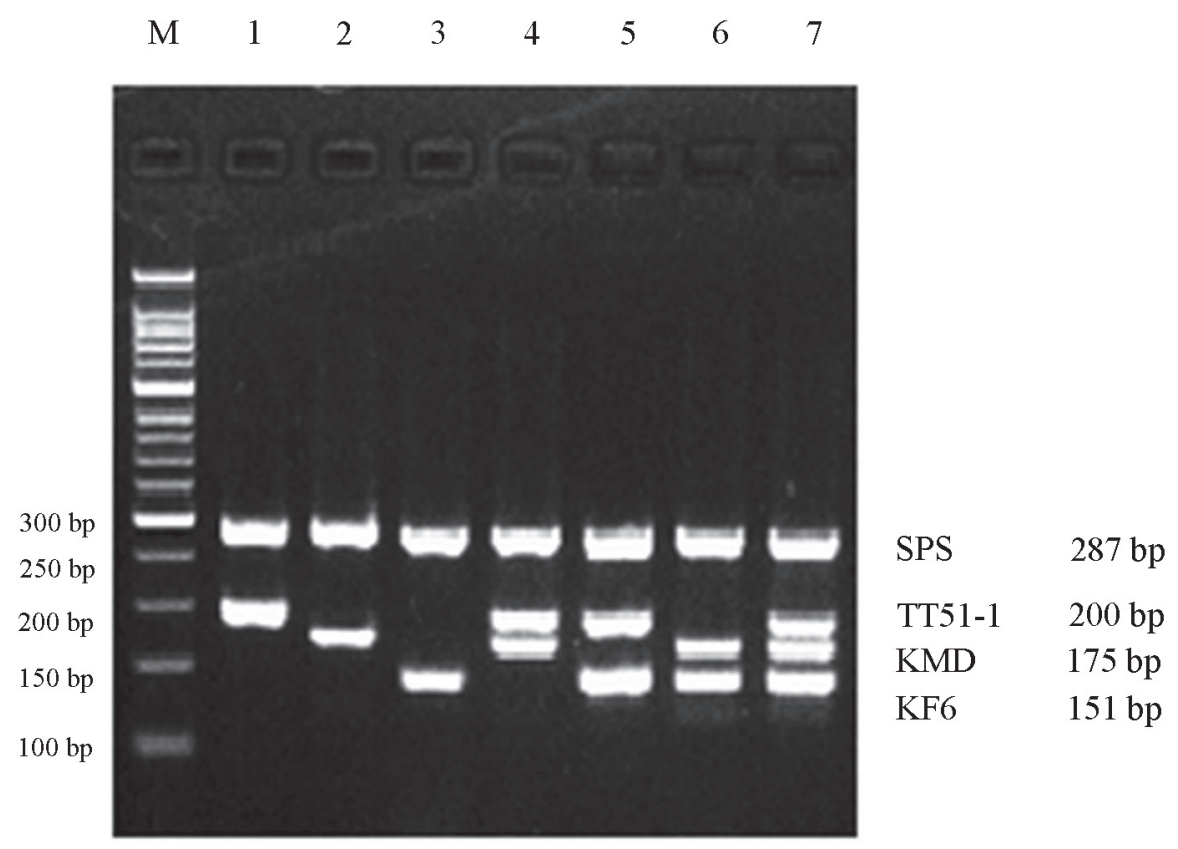

Figure 3. Multiplex PCR amplified from GM rice. Lane M, 50 bp DNA ladder; Lane 1, SPS and TT51-1; Lane 2, SPS and KMD; Lane 3, SPS and KF6; Lane 4, SPS, TT51-1 and KMD; Lane 5, SPS, TT51-1 and KF6; Lane 6, SPS, KMD and KF6; Lane 7, SPS, TT51-1, KMD and KF6 


\section{Limit of detection (LOD)}

To determine the limit of detection (LOD) of GM rice using this established multiplex PCR assay, a dilution series of rice gDNA mixture was prepared from three GM rice events and pure non-GM rice to be used as templates at various levels. The final relative GM contents were $10 \%, 5 \%, 1 \%, 0.5 \%, 0.1 \%, 0.05 \%$ and $0.01 \%$ (mass $/$ mass ratio) for each event of the three GM rice events, respectively. Three GM rices were mixed at the ratio 1:1:1 in mass. As shown in Fig. 4, the results revealed that the LOD value of this multiplex PCR is approximately $0.1 \%$.

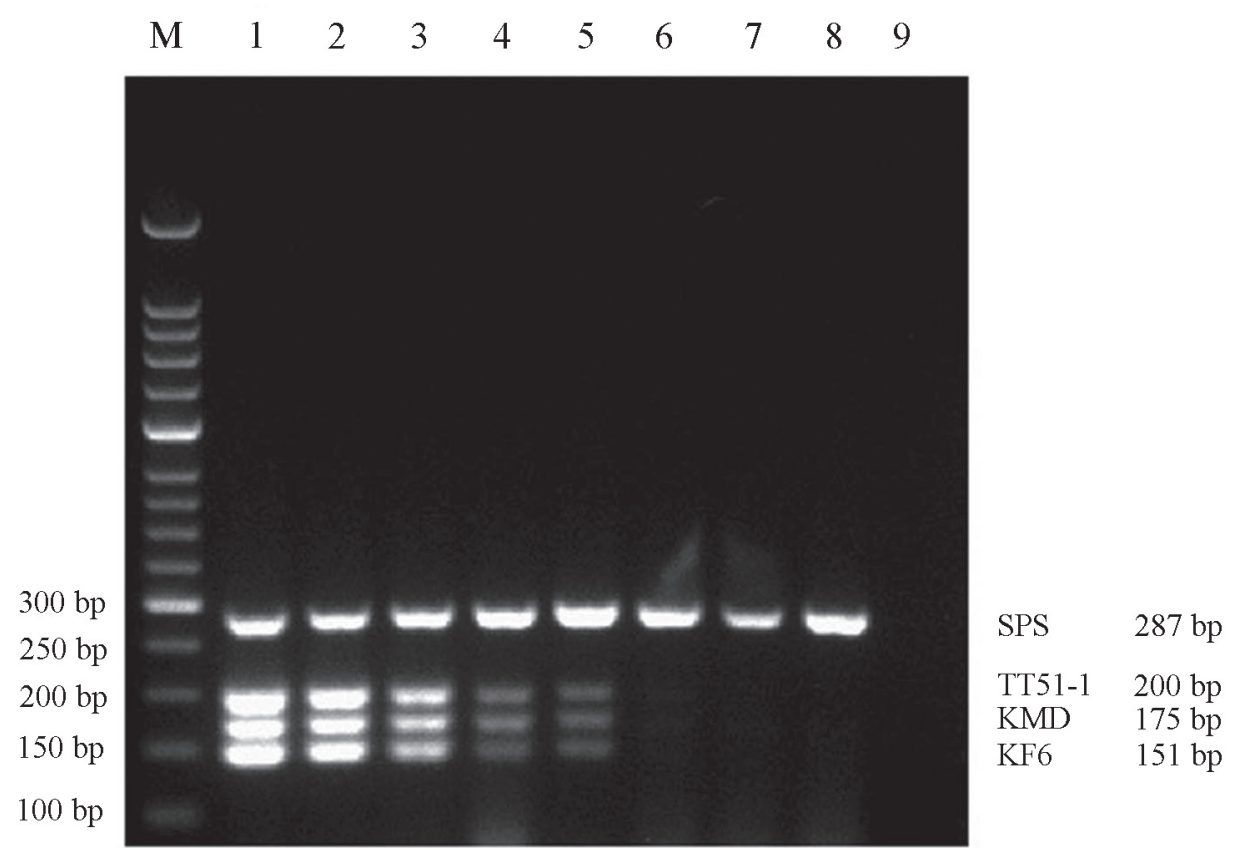

Figure 4. LOD analysis of the multiplex PCR. Lane M: marker (50 bp DNA Ladder); Lanes 1-7: 10\%, 5\%, $1 \%, 0.5 \%, 0.1 \%, 0.05 \%$, and $0.01 \%$ of a mixture of GM rice varieties (TT51-1, KMD and KF6); Lane 8: nonGM rice; Lane 9: no template

\section{Discussion}

For assured food safety and quality of GM crops and to address consumer concerns, efficient analytical methodologies must be available for GM testing (Rodríguez-Lázaro et al. 2007; Kamle et al. 2010). Hence, in order to monitor the potential present of illegal GM rice, the simple and effective detection methods are very urgent and much required. The introduction of a foreign gene into the DNA of an organism can be unambiguously detected at the DNA level (Heller 2003; Kamle et al. 2010). Hence, PCR-based transgene detection in GM crops remains the most sensitive method (Shrestha et al. 2010). The 
variant of PCR method, multiplex PCR method can be simultaneously performed of multiple event-specific sequences with more than one pair of primer sets in single-tube reactions and considered time-saving, low-cost and effective, as compared to the standard simplex PCR systems (Shrestha et al. 2010; You 2014). Multiplex PCR assays of different GMPs have been developed, such as GM soybean (Kim et al. 2009; Kim et al. 2013), GM cotton (Demeke et al. 2002; Kim et al. 2008; Yang et al. 2005), GM canola (Kim et al. 2007), and GM maize (Kim et al. 2014). In this study, multiplex PCR assay was developed for the qualitative detection of three GM rice genes amplified concurrently in a single PCR tube.

Primer design is critical in the multiplex PCR assay for the simultaneous amplification of multi-target DNA sequences to ensure specificity and sensitivity and to avoid crossreactions (Lee et al. 2014). As the number of primers increases, the interaction effects also increase and may result in the formation of amplification artifacts, such as primer-dimers, truncated DNA fragments, non-specific bands or an absence of bands (Shrestha et al. 2010). Although specific primers amplify target DNA sequences, they do so with the differential amplification rates (Kim et al. 2009). Taking into account these factors, lengths of multiple sets and melting temperatures (Tm) of primers must be similar (Kwon et al. 2014; Lee et al. 2014). To establish a multiplex PCR method for simultaneous detection of three events of GM rice, we designed event-specific primers targeting to three GM rice events, namely, TT51-1, KMD1 and KF6. Tm of primer pairs was maintained in the range of $49-62{ }^{\circ} \mathrm{C}$ in order to avoid the generation of nonspecific amplification. The optimal annealing temperature was found to be $61{ }^{\circ} \mathrm{C}$ in the multiplex PCR. The specificity of designed primer pairs was individually assessed by a simplex PCR assay. Only PCR products of the expected lengths were amplified from each target DNA, and no obvious non-specific signals were present in non-GM rice. Three events of GM rice were successfully detected by multiplex PCR using all the primer pairs.

In conclusion, we successfully developed a simple, reliable and cost-effective multiplex PCR assay for identifying genetic modifications of TT51-1, KMD1 and KF6 rice by using the event-specific fragment. The limit of detection (LOD) for each event in the multiplex PCR is approximately $0.1 \%$. The developed multiplex PCR method was so highly specific and sensitive and cost effective that it is useful to monitor GM rice in the markets around the world.

\section{Acknowledgements}

This work was supported by Central Public Research Institutes Basic Funds for Research and Development (Agro-Environmental Protection Institute, Ministry of Agriculture).

\section{References}

Arun, O.O., Yilmaz, F., Muratogolu, K. 2013. PCR detection of genetically modified maize and soy in mildly and highly processed foods. Food Control 32:525-531.

Babekova, R., Funk, T., Pecoraro, S., Engel, K.H., Busch, U. 2009. Development of an event-specific Real-time PCR detection method for the transgenic Bt rice line KMD1. Eur. Food Res. Technol. 228:707-716. 
Babekova, R., Funk, T., Engel, K.H., Baikova, D., Busch, U. 2008. Duplex polymerase chain reaction (PCR) for the simultaneous detection of cryIA(b) and the maize ubiquitin promoter in the transgenic rice line KMD1. Biotechnol. \& Biotechnol. Eq. 22:705-708.

Bahrdt, C., Krech, A.B., Wurz, A., Wulff, D. 2010. Validation of a newly developed hexaplex real-time PCR assay for screening for presence of GMOs in food, feed and seed. Anal. Bioanal. Chem. 396:2103-2112.

Cao, Y.L., Wu, G., Wu, Y.H., Nie, S.J., Zhang, L., Lu, C.M. 2011. Characterization of the transgenic rice event TT51-1 and construction of a reference plasmid. J. Agri. Food Chem. 59:8550-8559.

CERA 2010. GM Crop Database. Center for Environmental RiskAssessment (CERA), ILSI Research Foundation. Available at: http://www.cera-gmc.org/GMCropDatabase. Verified 2 January 2015.

Chen, X.Y., Wang, X.F., Jin, N., Zhou, Y., Huang, S.N., Miao, Q.M., Zhu, Q., Xu, J.F. 2012. Endpoint visual detection of three genetically modified rice events by loop-mediated isothermal amplification. Int. J. Mol. Sci. 13:14421-14433.

Chen, M., Shelton, A., Ye, G. 2011. Insect-resistant genetically modified rice in China: from research to commercialization. Annu. Rev. Entomol. 56:81-101.

Dellaporta, S.L., Wood, J., Hicks, J.B. 1983. A plant DNA minipreparation: version II. Plant Mol. Bio. Rep. 1:19-21.

Demeke, T., Giroux, R.W., Reitmeier, S., Simon, S.L. 2002. Development of a polymerase chain reaction assay for detection of three canola transgenes. J. Am. Oil Chem. Soc. 79:1015-1019.

Ding, J., Jia, J., Yang, L., Wen, H., Zhang, C., Liu, W., Zhang, D. 2004. Validation of a rice specific gene, sucrose phosphatesynthase, used as the endogenous reference gene for qualitative and real-time quantitative PCR detection of transgenes. J. Agr. Food Chem. 52:3372-3377.

Dong, W., Yang, L., Shen, K., Kim, B., Kleter, G.A., Marvin, H.J., Guo, R., Liang, W., Zhang, D. 2008. GMDD: A database of GMO detection methods. BMC Bioinformatics 9:260.

Ghareyazie, B. 2012. GMOs to be commercialized in Iran in the next five years. Food and Agriculture Organization's e-mail conference on GMOs in the pipeline: Looking to the next five years in the crop, forestry, livestock, aquaculture and agro-industry sectors in developing countries. Food and Agriculture Organization of the United Nations, Rome, Italy. Available at: http://www.fao.org/biotech/biotech-forum/ en/. Verified 6 June 2015.

GM Contamination Register 2007. Annual review of cases of contamination, illegal planting and negative side effects of genetically modified organisms 02/07. Greenpeace International, Amsterdam, The Netherlands. Available at: http://www.gmcontaminationregister.org/index.php?content=re\&handle2_page $=0 \&$ reg $=0 \&$ in $\mathrm{c}=0 \&$ con $=0 \&$ cof $=0 \&$ year $=2007$. Verified 6 June 2015 .

Heller, K.J. 2003. Detection of genetic modifications: some basic considerations. In: Heller, K.J. (ed.), Genetically Engineered Food: Methods and Detection. http://www.logobook.ru/prod_show.php?object_ uid=11062765 pp. $147-154$.

James, C. 2010. Global Status of Commercialized Biotech/GM Crops: 2010, ISAAA Briefs No.42, International Service for the Acquisition of Agri-biotech Application (ISAAA), Ithaca, NY, USA. Available at: http:// www.isaaa.org/resources/publications/briefs/42/. Verified 6 June 2015.

James, C. 2013. Global Status of Commercialized Biotech/GM Crops: 2013, ISAAA Brief No.46, International Service for the Acquisition of Agri-biotech Application (ISAAA), Ithaca, NY, USA. Available at: http:// www.isaaa.org/resources/publications/briefs/46/. Verified 6 June 2015.

Jiang, L., Yang, L., Zhang, H., Guo, J., Mazzara, M., Van, E.G., Zhang, D. 2009. International collaborative study of the endogenous reference gene, sucrose phosphate synthase (SPS), used for qualitative and quantitative analysis of genetically modified rice. J. Agr. Food Chem. 57:3525-3532.

Kamle, S., Kumar, A., Bhatnagar, R.K. 2010. Development of multiplex and construct specific PCR assay for detection of cry $2 \mathrm{Ab}$ transgene in genetically modified crops and product. GM Crops 2:74-81.

Kim, J.H., Jeong, D., Kim, Y.R., Kwon, Y.K., Rhee, G.S., Zhang, D., Kim, H.Y. 2013. Development of a multiplex PCR method for testing six GM soybean events. Food Control 31:366-371.

Kim, J.H., Zhang, D., Kim, H.Y. 2014. Detection of sixteen genetically modified maize events in processed foods using four event-specific pentaplex PCR systems. Food Control 35:345-353.

Kim, J.H., Seo, Y.J., Sun, S.H., Kim, H.Y. 2009. Multiplex PCR detection of 4 events of genetically modified soybeans (RRS, A2704-12, DP356043-5, and MON 89788). Food Sci. Biotechnol. 18:694-699. 
Kim, J.H., Kim, T.W., Lee, W.Y., Park, S.H., Kim, H.Y. 2007. Multiplex PCR detection of the GT73, MS8 $\times$ RF3, and T45 varieties of GM canola. Food Sci. Biotechnol. 16:104-109.

Kim, J.H., Kim, S.A., Seo, Y.J., Lee, W.Y., Park, S.H., Kim, H.Y. 2008. Multiplex PCR detection of the MON1445, MON15985, MON88913, and LLcotton 25 varieties of GM cotton. Food Sci. Biotechnol. 17:829-832.

Kluga, L., Folloni, S., Kagkli, D.M., Bogni, A., Foti, N., Savini, C., Mazzara, M., Van den Eede, G., Vanden Bulcke, M. 2013. Combinatory SYBR ${ }^{\circledR}$ green real-time pcr screening approach for tracing materials derived from genetically modified rice. Food Anal. Method. 6:361-369.

Kwon, J.Y., Hong, J.H., Kim, M.J., Choi, S.H., Min, B.E., Song, E.G., Kim, H.H., Ryu, K.H. 2014. Simultaneous multiplex PCR detection of seven cucurbit-infecting viruses. J. Viro. Methods 206:133-139.

Lee, N., Kwon, K.Y., Oh, S.K., Chang, H.J., Chun, H.S., Choi, S.W. 2014. A multiplex PCR assay for simultaneous detection of Escherichia coli O157:H7, Bacillus cereus, Vibrio parahaemolyticus, Salmonella spp., Listeria monocytogenes, and Staphylococcus aureus in Korean ready-to-eat food. Foodborne Pathog. Dis. 11:574-580.

Liu, Z., Li, Y., Zhao, J., Chen, X., Jian, G., Peng, Y., Qi, F. 2012. Differentially expressed genes distribute over chromosomes and implicated in certain biological processes for site insertion genetically modified rice Kemingdao. Int. J. Biol. Sci. 8:953-963.

Lu, C.M. 2010. The first approved transgenic rice in China. GM Crops I:113-115.

Reiting, R., Grohmann, L., Moris, G., Mäde, D. 2013. Detection and characterization of an unknown rice event in Basmati rice products. Eur. Food Res. Technol. 236:715-723.

Rodríguez-Lázaro, D., Lombard, B., Smith, H., Rzezutka, A., Agostino, D.M., Helmuth, R., Schroeter, A., Burkhard, M. 2007. Trends in analytical methodology in food safety and quality: monitoring microorganisms and genetically modified organisms. Trends Food Sci. Tech. 18:306-319.

Rong, J., Song, Z., Su, J., Xia, H., Lu, B.R., Wang, F. 2005. Low frequency of transgene flow from bt/cpti rice to its nontrangenic counterparts planted at clse spacing. New Phytol. 168:559-566.

Seck, P.A., Diagne, A., Mohanty, S.,Wopereis, M.C.S. 2012. Crops that feed the world 7: rice. Food Sec. 4:724.

Shrestha, H.K., Hwu, K.K., Chang, M.C. 2010. Advances in detection of genetically engineered crops by multiplex polymerase chain reaction methods. Trends Food Sci. Tech. 21:442-454.

Tu, J.M., Datta, K., Oliva, N., Zhang, G.A., Xu, C.G., Khush, G.S., Zhang, Q.F., Dattal, S.K. 2003. Siteindependently integrated transgenes in the elite restorer rice line Minghui 63 allow removal of a selectable marker from the gene of interest by self-segregation. Plant Biotechnol. J. I:155-165.

Wang, W., Zhu, T., Lai, F., Fu, Q. 2011. Event-specific qualitative and quantitative detection of transgenic rice Kefeng- 6 by characterization of the transgene flanking. Eur. Food Res. Technol. 232:297-305.

Wu, G., Wu, Y., Nie, S., Zhang, L., Xiao, L., Cao, Y., Lu, C. 2010. Real-time PCR method for detection of the transgenic rice event TT51-1. Food Chem. 119:417-422.

Yang, L.T., Pan, A.H., Zhang, K.W., Guo, J.C., Yin, C.S., Chen, J.X., Huang, C., Zhang, D.B. 2005. Identification and quantification of three genetically modified insect resistant cotton lines using conventional and TaqMan real-time polymerase chain reaction methods. J. Agr. Food Chem. 53:6222-6229.

Yang, L., Guo, J., Pan, A., Zhang, H., Zhang, K., Wang, Z., Zhang, D. 2007. Event-specific quantitative detection of nine genetically modified maizes using one novel standard reference molecule. J. Agric. Food Chem. 55:15-24.

You, M.J. 2014. Detection of four important Eimeria species by multiplex PCR in a single assay. Parasitol. Int. 63:527-532.

Zhang, D., Guo, J. 2011. The development and standardization of testing methods for genetically modified organisms and their derived products. J. Integr. Plant Biol. 53:539-551.

Zi, X. 2005. GM rice forges ahead in China amid concerns over illegal planting. Nat. Biotechnol. 23:637. 